\title{
Effect of Electrode Types on the Solidification Cracking Susceptibility of Austenitic Stainless Steel Weld Metal
}

\author{
J. U. Anaele, O. O. Onyemaobi, C. S. Nwobodo, and C. C. Ugwuegbu \\ Department of Materials and Metallurgical Engineering, Federal University of Technology, PMB 1526, Owerri, Nigeria \\ Correspondence should be addressed to J. U. Anaele; krimsysage@yahoo.com
}

Received 10 May 2015; Accepted 23 June 2015

Academic Editor: Peiqing La

Copyright ( 2015 J. U. Anaele et al. This is an open access article distributed under the Creative Commons Attribution License, which permits unrestricted use, distribution, and reproduction in any medium, provided the original work is properly cited.

\begin{abstract}
The effect of electrode types on the solidification cracking susceptibility of austenitic stainless steel weld metal was studied. Manual metal arc welding method was used to produce the joints with the tungsten inert gas welding serving as the control. Metallographic and chemical analyses of the fusion zones of the joints were conducted. Results indicate that weldments produced from E 308-16 (rutile coated), E 308-16(lime-titania coated) electrodes, and TIG welded joints fall within the range of $1.5 \leq \mathrm{Cr}_{\text {eq. }} / \mathrm{Ni}_{\text {eq. }} \leq 1.9$ and solidified with a duplex mode and were found to be resistant to solidification cracking. The E 308-16 weld metal had the greatest resistance to solidification cracking. Joints produced from E 310-16 had $\mathrm{Cr}_{\text {eq. }} / \mathrm{Ni}_{\text {eq. }}$ ratio $<1.5$ and solidified with austenite mode. It was found to be susceptible to solidification cracking. E 312-16 produced joints having $\mathrm{Cr}_{\text {eq. }} / \mathrm{Ni}_{\text {eq. }}$ ratio $>1.9$ and solidified with ferrite mode. It had a low resistance to solidification cracking.
\end{abstract}

\section{Introduction}

Stainless steel is a common name for steel alloys that consist of 10.5 weight percent or more of chromium $(\mathrm{Cr})$ and more than 50 weight percent of iron (Fe). Stainless steels may be classified by their crystalline structure into three main types: austenitic, ferritic, and martensitic stainless steel. Austenitic stainless steel (ASS) contains a maximum of 0.15 percent carbon, a minimum of 16 percent chromium, and sufficient nickel and/or manganese to retain an austenitic structure at all temperatures from the cryogenic temperature to the melting point of the alloy.

Austenitic stainless steels have become the most widely used stainless steels and correspond to about 70 percent of all the stainless steel produced worldwide, as a result of their mechanical and metallurgical properties and their good weldability [1]. The excellent properties of ASS which include high tensile strength, good impact resistance, excellent ductility, corrosion, and wear resistances have found various applications in domestic as well as in many engineering industries, some of which are cooking utensils, food processing equipment, equipment for chemical industry, truck trailers, kitchen sinks, exterior architecture, pressure boilers and vessels, fossil-fired power plant, fuel gas desulphurization equipment, evaporator tubing, super heater and reheating tubing, steam headers, and pipes, among others [2].

In recent times, advancement has been made in such joining process as adhesives, mechanical fasteners, brazing, and soldering. However, welding remains the most important metal joining process, even as arc welding is the most widely used fusion-welding process. In the fabrication of austenitic stainless steel components, welding is one of the most employed methods $[3,4]$. Despite the good weldability property exhibited by ASS, hot cracking has been the major metallurgical problem encountered during welding of austenitic stainless steel components. It is caused by the formation of low melting eutectics at the grain boundaries during welding, which cause failure under the action of shrinkage stresses associated with solidification. Solidification cracking is a type of hot cracking which depends on mechanical restraint and metallurgical susceptibility [5]. It consists of fractures at the interdendritic and/or intergranular weld metal boundaries in the solidification process, during which the liquid phase of the mushy melt becomes rich in impurities, mainly sulphur (S), and phosphorus (P). This phenomenon reduces the mechanical strength at the grain and dendritic boundaries, 


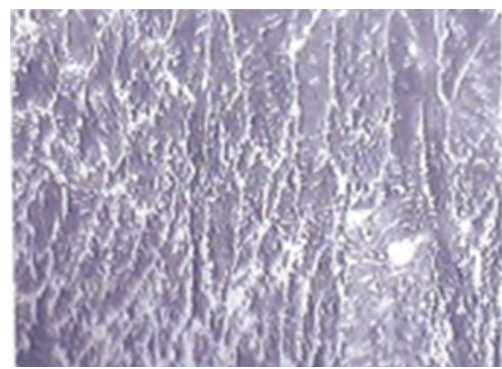

Magnification [200x]

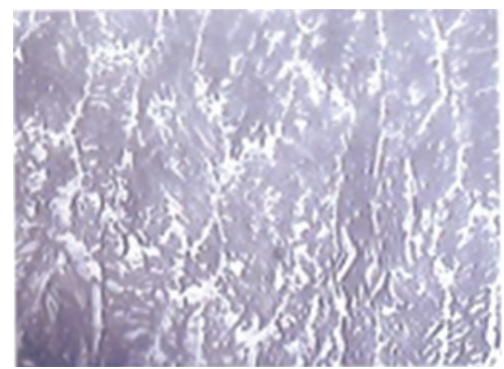

Magnification [400x]

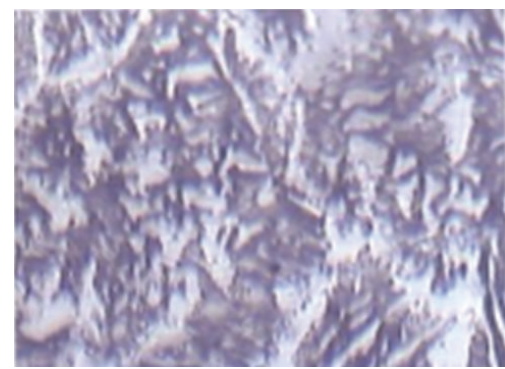

Magnification $[800 x]$

FIGURE 1: Fusion zone micrograph of E 312-16/10 welded joint.

rendering them susceptible to cracking and failure eventually [6]. One of such failures is the corrosion cracking of a grade 304 stainless steel pipe improperly seam welded and meant for the conveyance of glucose solution in Illinois USA [7].

In view of the problem of solidification cracking in ASS weldment, many works have been carried out in order to explain the phenomenon of solidification cracking and ways of preventing it. As early as 1941, Scherer et al. found that crack resistance in ASS weld metal may be improved by adjusting the composition to 5-35 percent ferrite in the completed weld. Hull [8] confirmed this by stating that when ferrite content in the completed weld increases beyond 35 weight percent, the weld metal would become susceptible to solidification cracking, but the mechanism by which crack resistance is achieved by the effect of retained ferrite in the weld metal is still not completely understood.

Good attempts, however, have been made to explain the effect. Borland and Younger [9] suggested that the higher solubility for impurity elements in delta ferrite leads to less interdendritic segregation and reduces cracking tendency. Thier et al. [10] found that the volume contraction associated with ferrite-austenite transformation reduces tensile stresses close to the crack tip, which decreases cracking tendency. Apart from the effect of retained delta ferrite in the control of solidification cracking in ASS weldment, Baldev et al. [5] and Borland [11] suggested that solidification cracking in ASS weld metal could be minimized by the various practices which reduce mechanical restraint in the completed weld metal. As can be seen in some of the research works cited above, solidification cracking in austenitic stainless steel weldment is partly a function of the weld metal composition. A well designed product, for example, can fail by cracking if the weld rod selected results in the weld zone having lower alloy content than that of the parent metal. Therefore, there is need to determine how the electrode type affects the solidification cracking susceptibility of ASS weldments. The main aim of this work is, therefore, to investigate the effect of electrode types on the microstructural susceptibility of the austenitic stainless steel weldment to solidification cracking.

\section{Material and Methods}

The base metal of the test specimens used for this study was type $304 \mathrm{H}$ austenitic stainless steel and the nominal chemical composition of the material is shown in Table 1.

Two methods of welding were adopted, namely, Shielded Metal Arc Welding (SMAW) and Tungsten Inert Gas (TIG)
TABLE 1: Chemical composition (wt.\%) of the austenitic stainless steel material.

\begin{tabular}{lc}
\hline Element & wt.\% \\
\hline $\mathrm{C}$ & 0.0570 \\
$\mathrm{Cr}$ & 18.5500 \\
$\mathrm{Ni}$ & 8.7200 \\
$\mathrm{Si}$ & 0.4400 \\
$\mathrm{Mn}$ & 1.7200 \\
$\mathrm{~S}$ & 0.0075 \\
$\mathrm{P}$ & 0.0230 \\
$\mathrm{Mo}$ & 1.7200 \\
$\mathrm{Al}$ & 0.0057 \\
$\mathrm{Cu}$ & 0.2010 \\
$\mathrm{Co}$ & 0.1110 \\
$\mathrm{Nb}$ & 0.0270 \\
$\mathrm{~V}$ & 0.0750 \\
$\mathrm{~B}$ & 0.0022 \\
$\mathrm{Sn}$ & 0.0086 \\
$\mathrm{As}$ & 0.0870 \\
$\mathrm{Ca}$ & 0.0004 \\
$\mathrm{Fe}$ & 69.8000 \\
\hline
\end{tabular}

Welding. The welding operations were conducted under constant condition as shown in Table 2.

The variable parameter in this study was the welding electrodes while the welded joints produced from TIG autogenous welding served as the control or reference for comparism. The chemical composition of the electrodes, according to American Welding Society (AWS) electrode classification, is shown in Table 3. The joints produced were subjected to metallographic test and chemical analysis.

\section{Results and Discussion}

3.1. Metallographic Analysis of the Weldments. The results obtained from the metallographic test conducted on the Fusion Zone of the each weldment were analyzed.

3.1.1. Analysis of E 312-16/10 Micrograph. The micrograph of E 312-16/10 fusion zone test specimen shown in Figure 1 revealed a primary ferrite (dark) matrix containing secondary austenite (white) and carbide precipitation at the grain boundaries. The ferrite dendrites being the first to solidify had a lathy morphology and partly transforms into austenite after solidification by diffusion controlled mechanism. 
TABLE 2: Welding parameters held constant in the welding operation.

\begin{tabular}{lcc}
\hline Welding parameters & Tungsten inert gas welding & Manual metal arc welding \\
\hline Welding current & $110 \mathrm{~A}$ & $110 \mathrm{~A}$ \\
Welding speed & $60 \mathrm{~mm} / \mathrm{min}$. & $60 \mathrm{~mm} / \mathrm{min}$. \\
Voltage & $40 \mathrm{~V}$ & $40 \mathrm{~V}$ \\
Polarity & DC electrode negative & DC electrode negative \\
Heat source & Arc & Arc \\
Weld pool shield & Argon gas & Electrode flux \\
Filler rod & $304 \mathrm{H}$ stainless steel wire & Welding electrode \\
Argon gas pressure & 10 bars & - \\
\hline
\end{tabular}

${ }^{*}$ Since the welding process was carried out manually, the welding speed is approximate and represents the average values.

TABLE 3: Chemical composition of the electrodes.

\begin{tabular}{|c|c|c|c|c|}
\hline Elements (wt.\%) & $\begin{array}{l}\text { E } 308-16 \text { (rutile coated) } \\
\text { Electrodes }(10 \text { \& 12) }\end{array}$ & $\begin{array}{c}\text { E 308-16 } \\
\text { (lime-titania) Electrode }\end{array}$ & $\begin{array}{l}\text { E } 310-16 \\
\text { Electrode }\end{array}$ & $\begin{array}{r}\text { E 312-16 } \\
\text { Electrode }\end{array}$ \\
\hline $\mathrm{C}$ & 0.08 & 0.08 & $0.08-0.12$ & 0.15 \\
\hline $\mathrm{Mn}$ & $0.7-2.0$ & $0.5-2.5$ & $1.0-2.5$ & $0.7-2.0$ \\
\hline $\mathrm{Si}$ & $0.3-0.85$ & 0.9 & $0.3-0.7$ & $0.3-0.9$ \\
\hline $\mathrm{Cr}$ & $18-21$ & $18-21$ & $25-28$ & $28-32$ \\
\hline $\mathrm{Ni}$ & $9-11$ & $9-11$ & $20-22$ & $8-10.5$ \\
\hline$S$ & 0.03 & - & 0.03 & 0.03 \\
\hline $\mathrm{P}$ & 0.03 & - & 0.03 & 0.03 \\
\hline Mo & 0.5 & - & 0.5 & 0.75 \\
\hline $\mathrm{Cu}$ & 0.75 & - & 0.75 & 0.75 \\
\hline
\end{tabular}

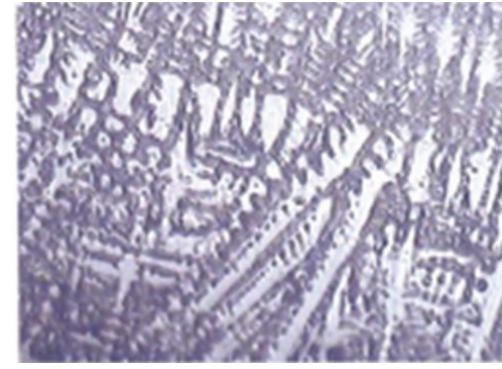

Magnification [200x]

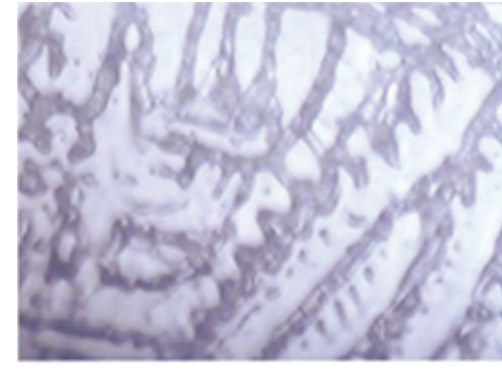

Magnification [400x]

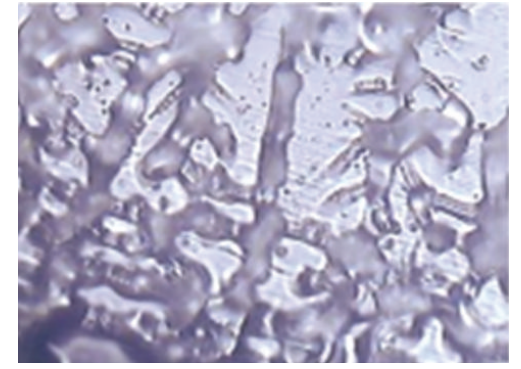

Magnification $[800 \mathrm{x}]$

FIGURE 2: Fusion zone micrograph of E 310-16/10 welded joint.

3.1.2. Analysis of E 310-16/10 Micrograph. E 310-16/10 fusion zone micrograph is shown in Figure 2. As can be seen from the micrograph, the primary austenite (white) formed directly from the liquid as a primary dendritic phase as well as a secondary phase around ferrite. The interdendritic ferrite (dark) had a vermicular morphology engulfed in the austenite matrix, with carbide precipitation along the grain boundaries.

3.1.3. Analysis of E 308-16/12 (Lime-Titania) Micrograph. Fu et al. [12] noted that ferrite-austenite (FA) solidification duplex mode is characterized by the formation of primary ferrite plus three phase (ferrite, austenite, and liquid) reactions at the terminal solidification stage. The fusion zone micrograph of E 308-16/12 (lime-titania) joint shown in Figure 3 revealed a plenty of fine colonies of lathy ferrite (dark) embedded in austenite (white) matrix. The result was a duplex microstructure consisting of thin lathy ferrite and austenite.

3.1.4. Analysis of TIG Micrograph. The fusion zone micrograph of TIG joint specimen shown in Figure 4 revealed primary equiaxed dendritic and lathy ferrite (dark) enclosed in austenite (white) matrix, with the precipitation of carbides along grain boundaries.

3.1.5. Analysis of E 308-16/12 (Rutile) Micrograph. The E 308$16 / 12$ (rutile) weld joint micrograph is shown in Figure 5. The figure revealed a duplex structure of ferrite and austenite. The primary ferrite (dark) dendrites having a combination of lathy and vermicular ferrite morphology contained in austenite (white) matrix and a precipitation of carbide along 


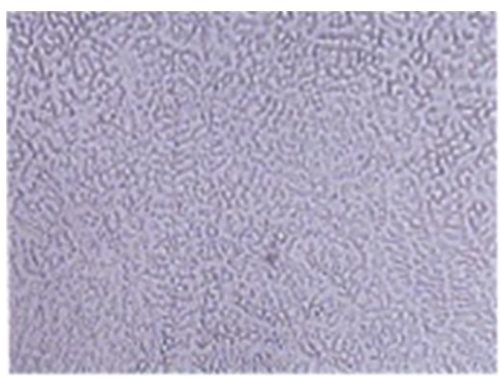

Magnification [200x]

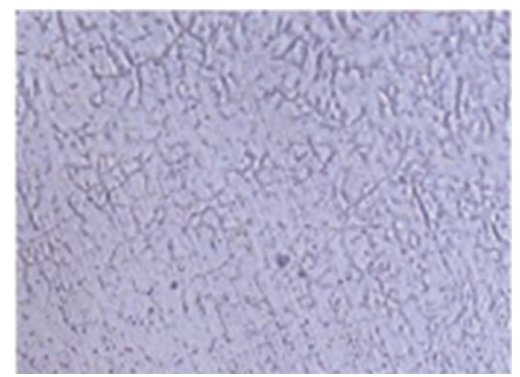

Magnification [400x]

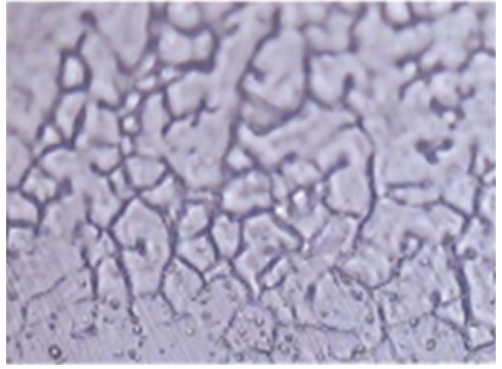

Magnification [800x]

FIGURE 3: Fusion zone micrograph of E 308-16/12 (lime-titania) welded joint.

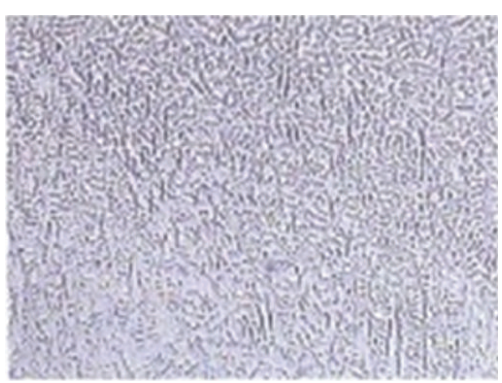

Magnification [200x]

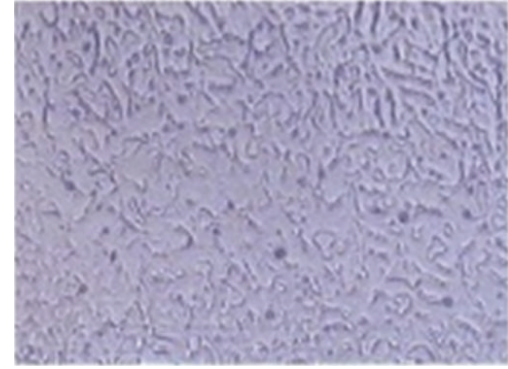

Magnification [400x]

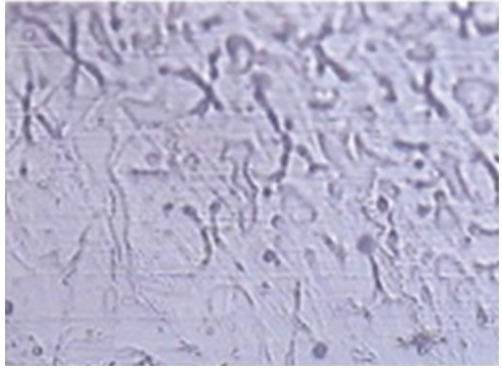

Magnification [800x]

Figure 4: Fusion zone micrograph of TIG welded joint.

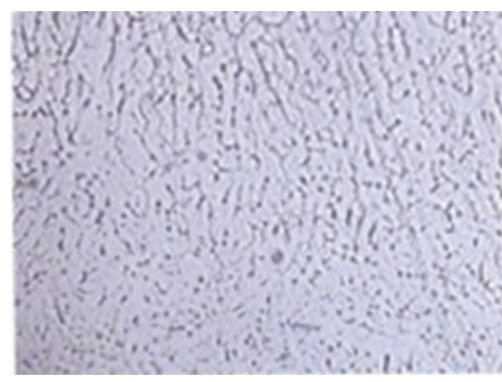

Magnification [200x]

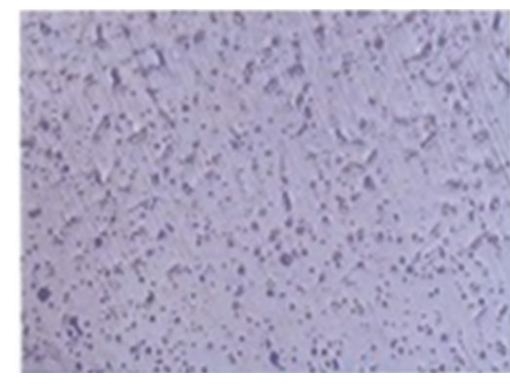

Magnification [400x]

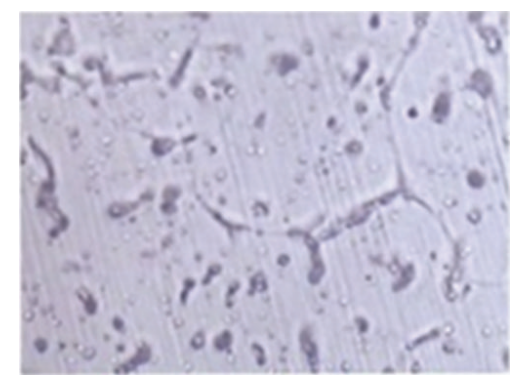

Magnification [800x]

FIgURE 5: Fusion zone micrograph of E 308-16/12 (rutile) welded joint.

grain boundaries. The amount of retained ferrite in E 30816/12 (rutile) weld metal was found to be less than TIG and E 308-16/12 (lime-titania) weld metals, respectively, but more than that observed in E 308-16/10 (rutile) weld metal.

3.1.6. Analysis of E 308-16/10 (Rutile) Micrograph. The fusion zone micrograph of the E 308-16/10 (rutile) joint shown in Figure 6 revealed a duplex structure consisting of ferrite (dark) and austenite (white). The primary ferrite had a thin lathy morphology engulfed by austenite which grew epitaxially and fills the interdendritic region of the primary ferrite. Carbide precipitation was also observed along the grain boundaries.

3.2. Effect of Electrode Types on the Solidification Mode of Austenitic Stainless Steel Weld Metal. The results displayed in Table 4 showed that the type of electrode selected in the welding of 304H stainless steel component affects the solidification microstructure of the weld metal. It was found that the TIG autogenous weld (Figure 4) had nearly the same solidification microstructure (FA) with the parent material (Figure 7), a result which was highly anticipated since there was no filler dilution in the completed weld as the tungsten electrode was nonconsumable. Weldments produced from E 308-16/12 (rutile), E 308-16/10 (rutile), and E 308-16/12 (lime-titania) electrodes had a duplex structure of ferriteaustenite (FA) with more or less amount of retained ferrite. Filler rod or electrode dilution is believed to be responsible for the evolved microstructure and solidification mode as shown in the results of the fusion zones micrographs of the $\mathrm{E}$ 308-16/12 (lime-titania), E 308-16/12 (rutile), and E 308-16/10 (rutile) joints displayed in Figures 3, 5, and 6, respectively. Joints produced from E 310-16/10 electrode (Figure 2) had austenite solidification mode whereas the joints made from 
TABLE 4: Values of $\mathrm{Cr}_{\text {eq. }}, \mathrm{Ni}_{\text {eq. }}, \mathrm{Cr}_{\text {eq. }} / \mathrm{Ni}_{\text {eq. }}$ ratio, and $(\mathrm{P}+\mathrm{S})$ wt.\% of the tested weld joints.

\begin{tabular}{lcccccc}
\hline Weld joints & $\mathrm{Cr}_{\text {eq. }}$ & $\mathrm{Ni}_{\text {eq. }}$ & $\mathrm{Cr}_{\text {eq. }} / \mathrm{Ni}_{\text {eq. }}$ & $(\mathrm{P}+\mathrm{S})$ wt.\% & Ferrite number $(\mathrm{FN})$ & Solidification mode \\
\hline E 308-16/12 (rutile) weld joint & 17.3019 & 9.7480 & 1.7750 & 0.0171 & 6 & Ferrite-austenite (FA) \\
E 308-16/10 (rutile) weld joint & 17.2042 & 9.8678 & 1.7435 & 0.0094 & $5-6$ & Ferrite-austenite (FA) \\
E 308-16/12 (lime-titania) joint & 19.8223 & 11.3915 & 1.7401 & 0.0086 & 10 & Ferrite-austenite (FA) \\
E 310-16/10 weld joint & 24.0273 & 22.7530 & 1.0560 & 0.0150 & $0-1$ & Austenite (A) \\
E 312-16/10 weld joint & 26.8069 & 12.9698 & 2.0669 & 0.0140 & $50-55$ & Ferrite (F) \\
TIG weld joint & 18.6387 & 10.9375 & 1.7041 & 0.0068 & & \\
\hline
\end{tabular}

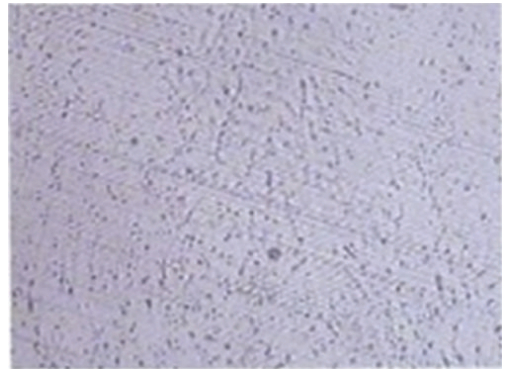

Magnification [200x]

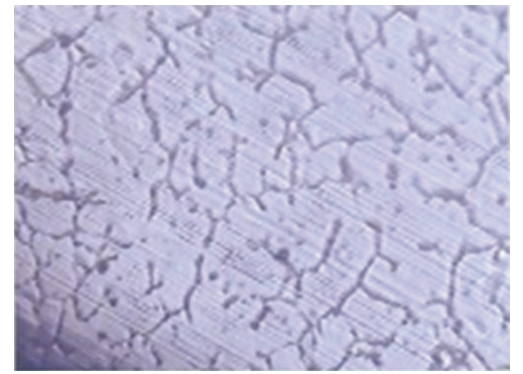

Magnification [400x]

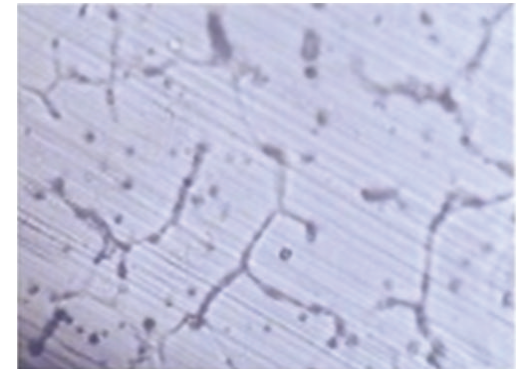

Magnification [800x]

FIgURE 6: Fusion zone micrograph of E 308-16/10 (rutile) welded joint.

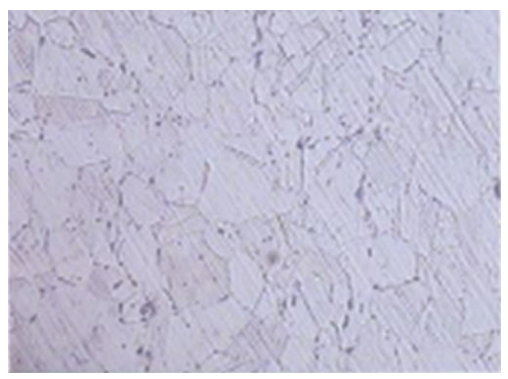

Magnification [200x]

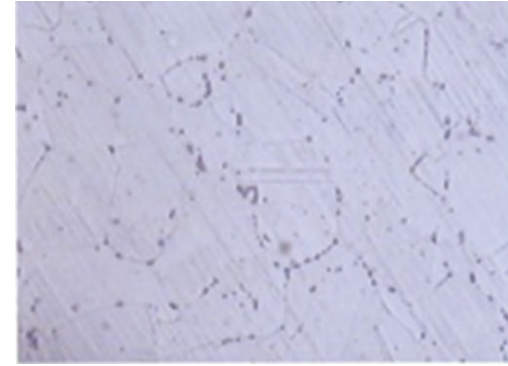

Magnification [400x]

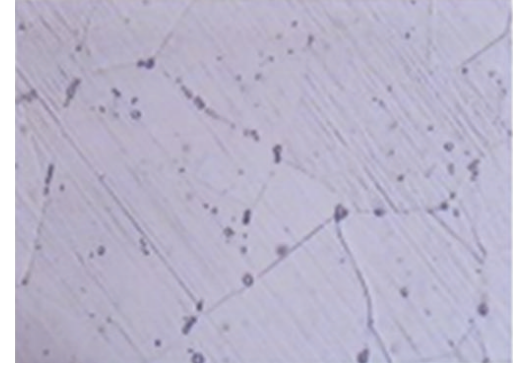

Magnification [800x]

FIGURE 7: Micrograph of the unwelded parent material.

E 312-16/10 (Figure 1) solidified with a primary ferrite solidification mode. The compromise reached between the parent material composition and filler rod or electrode dilution was found to be the major factor which determined the weld metal final microstructure and solidification mode. The findings of this research were found to be in line with the results of many researchers $[5,6,12-15]$.

\subsection{Effect of Electrode Types on Weld Metal Composition and} Cracking Propensity. The results of chemical analysis (presented in Table 5) carried out on the weldments showed that electrode types have effect on the weld metal composition. The TIG autogenous weldment had nearly the same composition and Chromium-Nickel equivalence as that of the unwelded parent metal. However, remarkable difference in weld metal constitution was observed in the joints produced from the various electrodes relative to the ChromiumNickel equivalence of the parent material. The ChromiumNickel equivalence results, calculated for each weld joints and presented in Table 4, were obtained by using the the
1992 Welding Research Council model equation culled from Kotecki and Siewert [16]:

$$
\begin{aligned}
& \mathrm{Cr}_{\text {eq. }}=\mathrm{Cr}+\mathrm{Mo}+0.7 \mathrm{Nb} \\
& \mathrm{Ni}_{\text {eq. }}=\mathrm{Ni}+35 \mathrm{C}+20 \mathrm{~N}+0.25 \mathrm{Cu},
\end{aligned}
$$

where, $\mathrm{Cr}_{\text {eq. }}=$ Chromium equivalent and $\mathrm{Ni}_{\text {eq. }}=$ Nickel equivalent.

The results showed that solidification cracking of the weld joints was sensitive to $\mathrm{Cr}_{\mathrm{eq}} / \mathrm{Ni}_{\mathrm{eq}}$. ratio and solidification mode of the welds. E 308-16/12 (lime-titania), TIG, E 308-16/12 (rutile), and E 308-16/10 (rutile) welds with primary ferrite-austenite solidification modes and $1.5<$ $\mathrm{Cr}_{\text {eq. }} / \mathrm{Ni}_{\text {eq. }}<1.9$ are immune to solidification cracking in the order of decreasing resistance to solidification cracking, respectively. E 312-16/10 weld with ferrite solidification mode and $\mathrm{Cr}_{\text {eq. }} / \mathrm{Ni}_{\text {eq. }}>1.9$ has low susceptibility to solidification cracking, whilst E 310-16/10 weld with primary austenite solidification mode, $\mathrm{Cr}_{\text {eq. }} / \mathrm{Ni}_{\text {eq. }}<1.5$, and $(\mathrm{P}+\mathrm{S})$ wt. $\%=$ 0.015 may be susceptible to solidification cracking. Filler rod 
TABle 5: Chemical composition of the weld joints.

\begin{tabular}{|c|c|c|c|c|c|c|}
\hline Elements wt.\% & $\begin{array}{l}\text { E 308-16/12 } \\
\text { (rutile) weld }\end{array}$ & $\begin{array}{l}\text { E } 308-16 / 10 \\
\text { (rutile) weld }\end{array}$ & $\begin{array}{c}\text { E 308-16/12 } \\
\text { (lime-titania) weld }\end{array}$ & E $310-16 / 10$ weld & E 312-16/10 weld & TIG weld \\
\hline Carbon, C & 0.0710 & 0.0730 & 0.0740 & 0.1350 & 0.0920 & 0.0600 \\
\hline Silicon, S & 0.6900 & 0.6300 & 0.4900 & 0.5100 & 0.9100 & 0.3760 \\
\hline Manganese, Mn & 1.2200 & 1.1800 & 1.3900 & 1.8700 & 1.3200 & 1.6200 \\
\hline Phosphorus, $\mathrm{P}$ & 0.0061 & 0.0010 & 0.0010 & 0.0010 & 0.0010 & 0.0022 \\
\hline Sulphur, S & 0.0110 & 0.0084 & 0.0076 & 0.0140 & 0.0130 & 0.0046 \\
\hline Chromium, Cr & 17.1500 & 17.0200 & 19.5700 & 23.8500 & 26.7100 & 18.4500 \\
\hline Nickel, Ni & 7.1900 & 7.2100 & 8.7400 & 17.9900 & 9.7300 & 8.7900 \\
\hline Molybdenum, Mo & 0.1330 & 0.1660 & 0.2320 & 0.1570 & 0.0640 & 0.1740 \\
\hline Aluminium, Al & 0.0055 & 0.0049 & 0.0056 & 0.0170 & 0.0072 & 0.0055 \\
\hline Copper, $\mathrm{Cu}$ & 0.2920 & 0.4110 & 0.2460 & 0.1520 & 0.0790 & 0.1900 \\
\hline Cobalt, Co & 0.0830 & 0.0960 & 0.1120 & 0.0770 & 0.0640 & 0.1170 \\
\hline Titanium, Ti & 0.0240 & 0.0190 & 0.0110 & 0.4250 & 0.0160 & 0.0010 \\
\hline Niobium, $\mathrm{Nb}$ & 0.0270 & 0.0260 & 0.0290 & 0.0290 & 0.0470 & 0.0210 \\
\hline Vanadium, V & 0.0680 & 0.0700 & 0.1050 & 0.1080 & 0.1190 & 0.0770 \\
\hline Tungsten, W & 0.0100 & 0.0100 & 0.0100 & 0.0100 & 0.0100 & 0.0560 \\
\hline Lead, $\mathrm{Pb}$ & 0.0034 & 0.0030 & 0.0030 & 0.0030 & 0.0030 & 0.0038 \\
\hline Boron, B & 0.0021 & 0.0018 & 0.0016 & 0.0017 & 0.0012 & 0.0022 \\
\hline Tin, Sn & 0.0100 & 0.0098 & 0.0090 & 0.0075 & 0.0110 & 0.0110 \\
\hline Arsenic, As & 0.0860 & 0.0810 & 0.0930 & 0.0960 & 0.1160 & 0.0950 \\
\hline Bismuth, Bi & 0.0015 & 0.0015 & 0.0015 & 0.0015 & 0.0015 & 0.0015 \\
\hline Calcium, Ca & 0.0002 & 0.0002 & 0.0003 & 0.0024 & 0.0003 & 0.0003 \\
\hline Iron, Fe & 72.9000 & 73.0000 & 68.9000 & 54.6000 & 60.7000 & 69.9000 \\
\hline
\end{tabular}

or electrode dilution is one of the factors which determined the final weld metal composition and solidification mode. Since solidification cracking is sensitive to weld metal composition and solidification mode, it therefore follows that the type of electrode used during welding of ASS materials determines the weld metal solidification cracking propensity.

These results were compared with the cracking susceptibility of 300 series stainless steel based on $\mathrm{Cr}-\mathrm{Ni}$ equivalence according to Hammar and Svensson [17] and found to be consistent and also in line with the findings of Arantes and Trevisan [6], Baldev et al. [5], Korinko and Malene [18], and Brooks and Thompson [19] who affirmed that the propensity for solidification cracking in austenitic stainless steel is sensitive to the $\mathrm{Cr}_{\text {eq. }} / \mathrm{Ni}_{\text {eq. }}$ ratio, $(\mathrm{P}+\mathrm{S})$ wt.\%, and ferrite number of the weld metal and maintained that weld metal with solidified FA mode in the range of $1.5<$ $\mathrm{Cr}_{\text {eq. }} / \mathrm{Ni}_{\text {eq. }}<1.9$ is immune to solidification cracking, while those in the region of $\mathrm{Cr}_{\text {eq. }} / \mathrm{Ni}_{\text {eq. }}>1.9$ and $\mathrm{Cr}_{\text {eq. }} / \mathrm{Ni}_{\text {eq. }}<1.5$ have low resistance and susceptible to solidification cracking, respectively. Generally, it was found that $(\mathrm{P}+\mathrm{S})$ wt.\% values were less than 0.02 in the final composition of the respective welded joints, which is below the critical level suggested by Arantes and Trevisan [6], necessary to induce cracking.

The results also suggest that the type of electrode coating has effect on the weld metal properties. The electrodes used for the welding were designated "-16" which denotes rutile coating for stainless steel electrodes. Rutile coatings are titania-type based electrodes containing little proportion of other additives. However, E 308-16/12 (lime-titania) electrodes were coated with titanium calcium and contain lime which makes it distinct from the rutile category. The presence of lime (which is a slag former) in E 308-16/12 (lime-titania) electrode was relevant in slowing down the cooling rate of both the weld pool and the just solidified weld metal of the resultant weldment. This suggests the reason for the slight difference observed in properties (such as ductility and strain hardening exponent) of weldments produced from the E 30816 (lime titania) with respect to E 308-16 (rutile) welding electrodes. Consequently, the weldment produced from $\mathrm{E}$ $308-16 / 12$ (lime-titania) electrode has a higher ductility of about $36 \%$ (in terms of percentage elongation) compared to $26 \%$ and $18 \%$ obtained from weldments produced from E 308-16/10 (rutile) and E 308-16/12 (rutile) electrodes, respectively. This result is confirmed in the micrograph of E 308-16/12 (lime-titania) weldment which suggests that the ferrite dendrite had more time for growth in the region where delta ferrite is most stable (due to slower cooling rate offered by lime in the electrode coating) compared to the micrographs of E 308-16/10 (rutile) and E 308-16/12 (rutile) weldments. 


\section{Conclusion}

The cracking of austenitic stainless steel (ASS) material during welding was successfully reviewed while investigating the microstructural propensity of an ASS component to solidification cracking. It was found that fabricated ASS components produced from E 308-16/12 (rutile), E 308-16/10 (rutile), E 308-16/12 (lime-titania) electrodes, and TIG joints (all having FA duplex mode of solidification and ratio of $\mathrm{Cr}$ to $\mathrm{Ni}$ equivalence in the range $1.5<\mathrm{Cr}_{\text {eq. }} / \mathrm{Ni}_{\text {eq. }}<1.9$ ) are resistant to solidification cracking. The E $308-16 / 12$ (lime-titania) electrode (having ferrite number (FN) of 10) was observed to impact the highest resistance to cracking, followed by TIG joints (with FN of 8), E 308-16/12 (rutile) with FN = 6 , and $\mathrm{E} 308-16 / 10$ (rutile) with $\mathrm{FN}=5.5$ in that order. ASS components fabricated from E 312-16/10 electrode (produced a $\mathrm{Cr}_{\text {eq. }} / \mathrm{Ni}_{\text {eq. }}$ ratio of about 2.01 which is greater than 1.9 and ferrite number of about $53 \%$ in the completed weld which is beyond $35 \%$ stipulated by Hull [8] and necessary to cause a shift from immunity zone to crack susceptible zone). They solidified with a ferrite mode and were found to show little resistance to solidification cracking. The E 310-16/10 electrode solidified with austenite mode and was found to be somewhat liable to solidification cracking since it produced a $\mathrm{Cr}_{\mathrm{eq}} / \mathrm{Ni}_{\mathrm{eq}}$. ratio of about 1.01, which is less than 1.5 the value suggested by $[6,19-21]$ to prevent solidification cracking in the completed weld metal.

\section{Conflict of Interests}

The authors declare that there is no conflict of interests regarding the publication of this paper.

\section{References}

[1] Y. Cui, C. D. Lundin, and V. Hariharan, "Mechanical behavior of austenitic stainless steel weld metals with microfissures," Journal of Materials Processing Technology, vol. 171, no. 1, pp. 150-155, 2006.

[2] A. Galal, N. F. Atta, and M. H. S. Al-Hassan, "Effect of some thiophene derivatives on the electrochemical behaviour of AISI 316 austenitic stainless steel in acidic solutions containing chloride ions," Materials Chemistry and Physics, vol. 89, no. 1, pp. 38-48, 2005.

[3] A. S. Afolabi, "Effect of electric arc welding parameters on corrosion behavior of austenitic stainless steel in chloride medium," AU Journal of Technology, vol. 11, no. 3, pp. 171-176, 2008.

[4] F. A. Ovat, L. O. Asuquo, and A. J. Anyandi, "Microstructural effects of electrodes types on the mechanical behavior of welded steel joints," Research Journal in Engineering and Applied Sciences, vol. 1, no. 3, pp. 171-176, 2012.

[5] R. Baldev, V. Shankar, and A. K. Bhaduri, Welding Technology for Engineers, Narosa Publishing House, New Delhi, India, 2006.

[6] F. M. L. Arantes and R. E. Trevisan, "Experimental and theoritical evaluation of solidification cracking in weld metal," Journal of Achievements in Materials and Manufacturing Engineering, vol. 20 , no. 1-2, 2007.

[7] G. K. James, Chronology of Corrosion Disaster, vol. 5, American Society for Metals, New York, NY, USA, 2000.

[8] F. C. Hull, "The effect of $\delta$-ferrite on the hot cracking of stainless steel," Welding Journal, vol. 46, pp. 399-409, 1967.
[9] J. C. Borland and R. N. Younger, "Some aspects of cracking in welded Cr-Ni austenitic steels," British Welding Journal, vol. 7, pp. 22-59, 1960.

[10] H. Thier, R. Killing, and U. Killing, "Solidification modes of weldmentsIn corrosion resistant steels-how to make them visible," Metal Construction, vol. 19, no. 3, pp. 127-130, 1987.

[11] J. C. Borland, "Generalized theory of supersolidus cracking in welds and castings," British Welding Journal, vol. 7, pp. 508-512, 1960.

[12] J. W. Fu, Y. S. Yang, and J. J. Guo, "Formation of a blocky ferrite in $\mathrm{Fe}-\mathrm{Cr}-\mathrm{Ni}$ alloy during directional solidification," Journal of Crystal Growth, vol. 311, no. 14, pp. 3661-3666, 2009.

[13] A. Di Schino, M. G. Mecozzi, M. Barteri, and J. M. Kenny, "Solidification mode and residual ferrite in low-Ni austenitic stainless steels," Journal of Materials Science, vol. 35, no. 2, pp. 375-380, 2000.

[14] G. L. Leone and H. W. Kerr, The Ferrite to Austenite Transformation in Stainless Steels, Welding Research Supplement, 1982.

[15] T. Udomphol, "Solidification and phase transformations in welding," Lecture Material, Suranaree University of Technology, India, 2007.

[16] D. J. Kotecki and T. A. Siewert, "WRC-1992 constitution diagram for stainless steel weld metals: a modification of the WRC1988 diagram," Welding Journal, Research Supplement, vol. 71, no. 5, pp. 171-177, 1992.

[17] O. Hammar and U. Svensson, "Influence of steel composition on segregationAnd microstructure during solidification of austenitic stainless steel," in Solidification and Casting of Metals, pp. 401-410, The Metal Society, London, UK, 1979.

[18] P. S. Korinko and S. H. Malene, "Considerations for the weldability of types 304L and 316L stainless steel," Practical Failure Analysis, vol. 1, no. 4, pp. 61-68, 2001.

[19] J. A. Brooks and A. W. Thompson, "Microstructural development and solidification cracking susceptibility of austenitic stainless steel welds," International Materials Reviews, vol. 36, no. 1, pp. 16-44, 1991.

[20] V. Shankar, T. P. S. Gill, S. L. Mannan, and S. Sundaresan, "Solidification cracking in austenitic stainless steel welds," Sadhana, vol. 34, no. 3-4, pp. 359-382, 2003.

[21] R. Scherer, G. Riedrich, and H. Hougardy, "Welding rod," US Patent 2240672, 1941. 

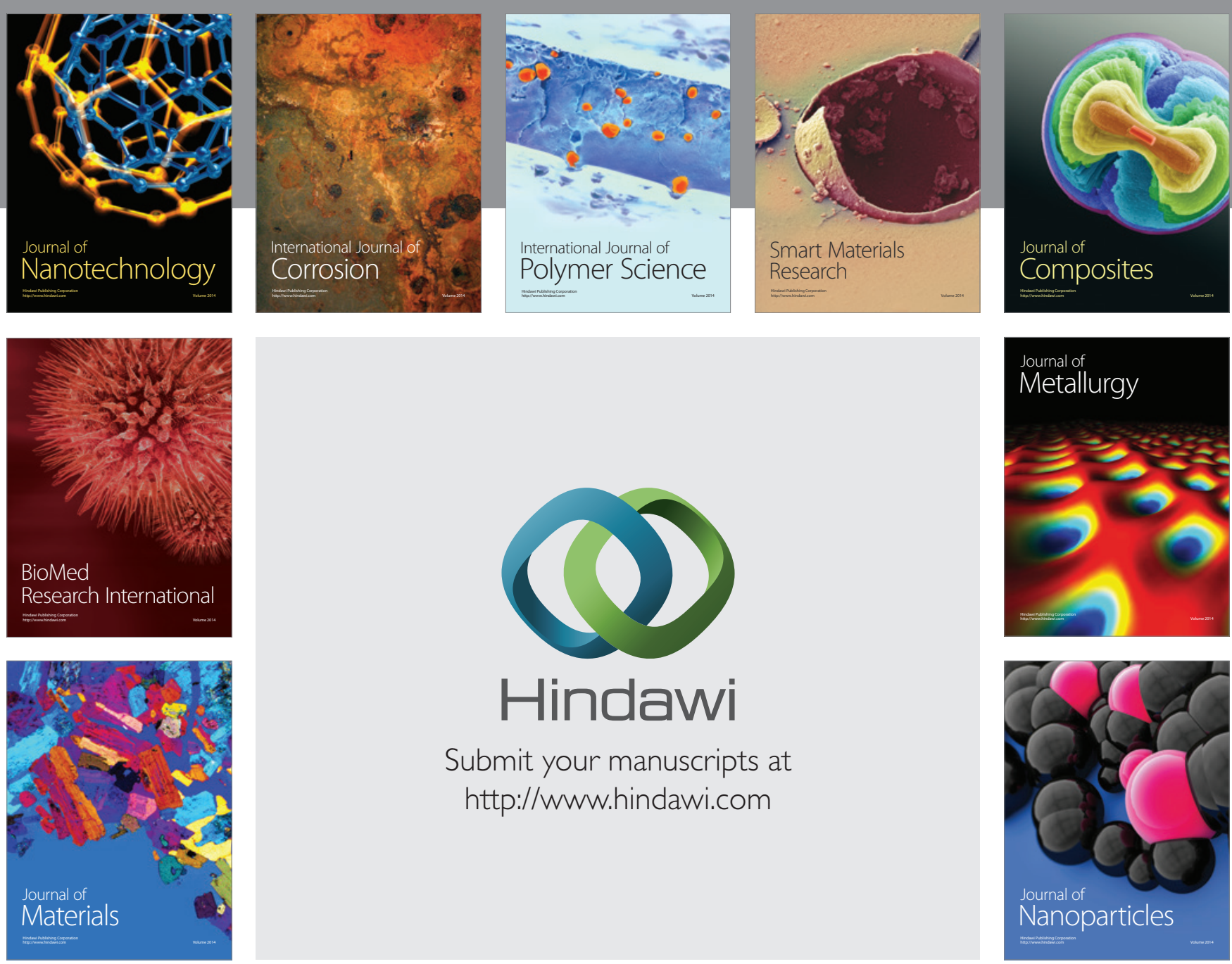

Submit your manuscripts at http://www.hindawi.com
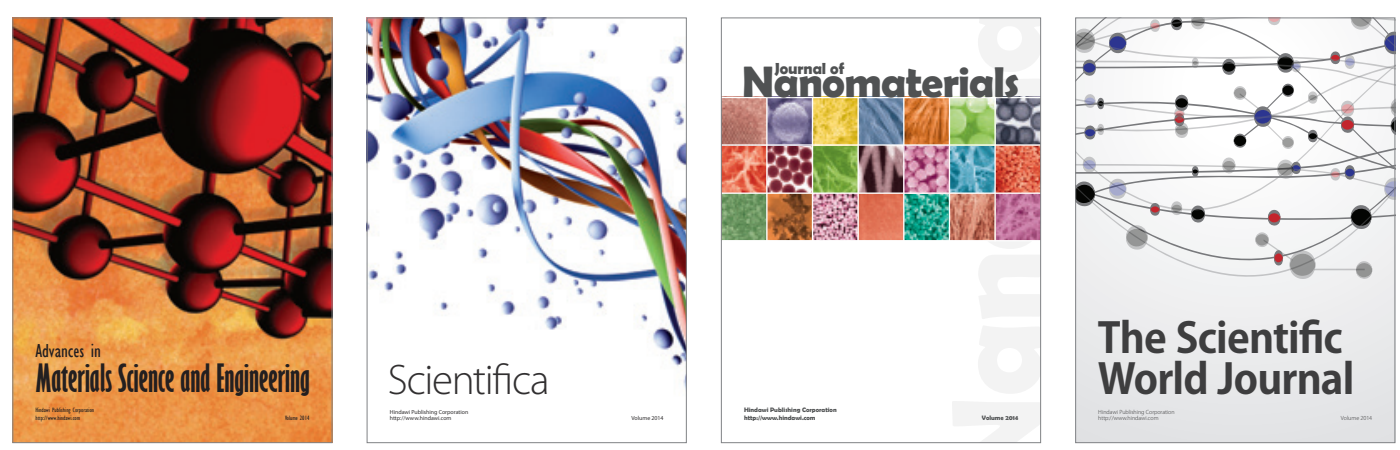

\section{The Scientific World Journal}
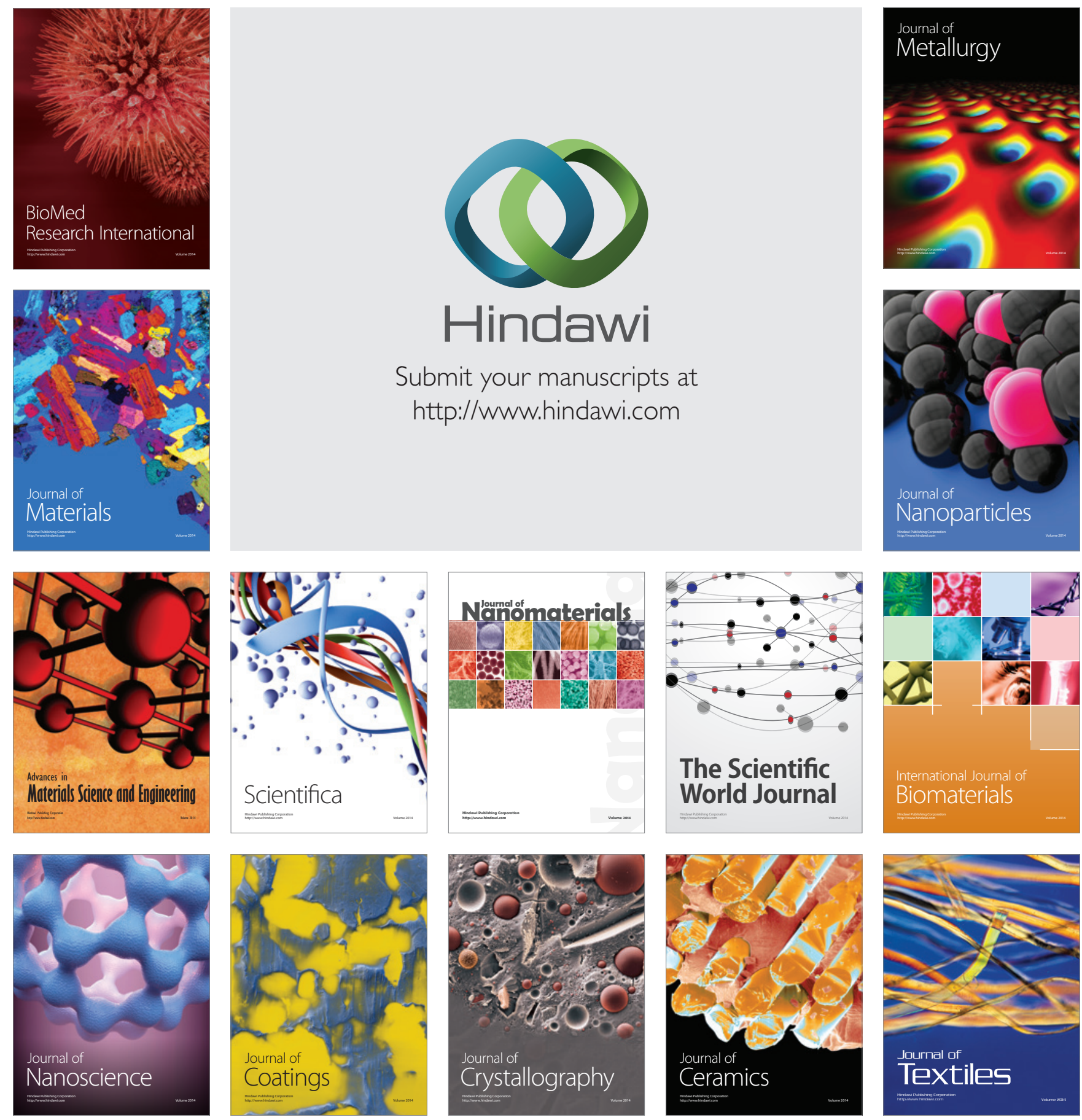